\title{
Microsporum equinum
}

National Cancer Institute

\section{Source}

National Cancer Institute. Microsporum equinum. NCI Thesaurus. Code C127734.

A species of fungi in the phylum Ascomycota with macroconidia that are small, broad, irregular, and spindle-shaped with rough thick walls and few septa. This species is a causative agent of ringworm in horses and humans. 